\title{
LANGUAGE FUNCTION USED IN “NOW YOU SEE ME 2 MOVIE”: PURPOSE ANALYSIS OF LITERARY WORD
}

\author{
Olya Octa Devia Putri \\ University of Bengkulu \\ , e-mail :Olyaoctadeviaputri@gmail.com \\ Safnil \\ University of Bengkulu, \\ e-mail : Safnilarsyad@gmail.com \\ Kasmaini \\ University of Bengkulu, \\ e-mail : kasmainiunib@gmail.com
}

\begin{abstract}
The aim of this research was to find outthe kinds of language function used and the distributions of frequency of language function by the main characters in "Now You See Me 2 Movie". This research was conducted by using mixed method research. The instrument of this research was table checklist. The data were collected by the researcher and co-researcher through deep analysis of movie's script. The result of the study showed that there were only five language functions found in the movie out of six language functions. They are referential function, phatic function, emotive function, conative function, and metalingual function. The distribution of language function frequency in "Now You See Me 2 Movie" isreferential funcion $(35.2 \%$ ?), phatic function $(25.5 \%)$, emotive function $(21,0 \%)$, conative function $(15.8 \%)$, metalingual function $(2.5 \%)$ and poetic function $(0 \%)$. Based on theexplanation, refrential function is the most dominant language function used in the movie. The distribution was possibly caused by the genre of the movie. The genre of the movie was spy-thriller, in which the most commonly used expression was to the point, imperative, and straight foward.
\end{abstract}

Keywords: Language, Language Function, Movie, Script

\begin{abstract}
Abstrak
Tujuan dari penelitian ini adalah untuk menemukan macam-macam fungsi bahasa yang digunakan dan penyebaran fungsi bahasa oleh para pemeran-pemeran utama di film "Now You See Me 2". Penelitian ini menggunakan metode gabungan penelitian. Instrumen dari penelitian ini adalah ceklish tabel. Pengumpulan data dilakukan oleh peneliti dan pembantu penelitimelalui analisis yang mendalam terhadap naskah film. Hasil penelitian menunjukan bahwa hanya lima fungsi bahasa yang ditemukan di film dari enam fungsi bahasa. Fungsifungsi itu adalah, fungsi referensial, fungsi phatik, fungsi emotif, fungsi konatif, dan fungsi metalingual. Penyebaran dari frekuensi fungsi bahasa di film "Now You See Me 2" adalah fungsi referensial (35.2\%), fungsi phatik (25.5\%), fungsi emotif $(21,0 \%)$, fungsi konatif (15.8\%) fungsi metalingual $(2.5 \%)$, dan fungsi puitik $(0 \%)$. Berdasarkan penjelasan, fungsi referensial merupakan fungsi yang paling banyak digunakan di film. Penyebarannya kemungkinan disebabkan oleh genre dari film itu sendiri. Genre dari film ini adalah spythriller, dimana ekspresi yang biasanya digunakan berupa ungkapan langsung, ungkapan perintah dan ungkapan terus terang.
\end{abstract}

Kata kunci:Bahasa, Fungsi Bahasa, Film, naskah. 


\section{INTRODUCTION}

Language is a system of communication consisting of sound, words, and grammar or the system of communication used by people in a particular country. Communication is divided into two kinds: verbal communication and non verbal communication. Verbal communication is oral language or communication by using word said. According to Hasist (2007), non verbal communication is a communication by using media such as article. Based on the context of language, in talking about language people must know about the function of language itself. Arwood (2011) states that language function is to develop a human's social, cognitive being and greater than the sum of the structures.

Since the technology has advanced, people can learn language function in many ways, such as reading book, watching film or movie, listening music and others. Movie is one of medium in which we can find many language functions. According to Bordwell and Thompson (2008), film is a form of art with an aesthetic and a language all its own. Everyone likes watching movie, from children to adults. They can stay on the TV to watch their favorite movies or films.

Movie is simply short of motion pictures (Barsam, 2010). It is produced by creating images using animation techniques or visual effects or by recording photographic images with cameras. According Bordwell and Thompson (2008), there are two principal ways of grouping films. The first way is by genre and the second way is by some conception of the film's relation to reality (its manner of production).

As we know that, not everyone can easy understand a movie because movie or film uses oral language. Many implisit meanings in a movie can be found. It makes them difficult to understand the meanings or messages contained in the movie. Based on informal interview of students in fifth semester in Universitas Bengkulu, the researcher found some problems in watching film or movie. The common problems experienced by students in watching movie were new vocabulary or unfamiliar words, grammar or function grammar (including language function) and others.

One of the problems was language function. It was occured because this object has not taught in detail. So, the researcher chooses language function as the object of the research because the reseracher wants to know how deep the students understand about language function and how far they are understanding it by recognizing those language function in a movie.

This study, the researcher chooses Now You See Me 2 movie, because this movie has many viewer especially English students of Universitas Bengkulu in 21 cinema Mega Mall Bengkulu. Now you See Me 2 Movie is an American movie with the genre spy-thriller in 2016 which is a sequel movie of Now You See Me (2013). Spy thriller genre is one kinds of the sub-genre thriller. This sub-genre focuses on the travels and adventure of agents in the office or out of the field. This movie uses some unexpected trick to make the viewer agaze and schock. The story of the movie is about magic trick and the author made this movie looked so real by using a real trick magic. Many unpredictable incidents happend and it was out of our logic. This movie tells us about the next job for "The Horsemen" who wants to expose the unethical practices of a tech magnate by Walter Mabry.

The research questions of the study are: what kinds of language function are found in "Now You See Me 2 Movie" 
based on Jakobson's theory? and How is the distribution of language function frequency found in "Now You See Me2 Movie"?. This research focuses on the language functions used by the main characters of this movie. They are Dyland Rhodes, Daniel Atlas, Jack Wilder, Merritt McKnney and Lula.

In general, language function is the purpose of speaking that sentence or pharase. According to Jakobson (1987), language function must be invertigated in all the variety of its functions. There are sixs function of language function based on Jakobson's theory, they are: refrential function, emotive function, conative function, phatic function, metalingual function and poetic function.

Referential function is the utterance associated with an orientation toward the context (Jakobson, 1987). For example: Water boils at 100 degrees. Emotive function is expressive function, focusing on the aims a direct expression of the speaker's attitude toward what he /she is going to speak about. For example: "bah!", “oh!', “ouch!”. Conative function is the purest gramatical expression in the vocative and imperative sentence. For example: "Zidan! Come inside and eat!". Phatic function is opening or checkingthe channelthat it is working(Cook, 1989). According to Jakobson (1987), phatic function is the utterance associated with an oriented toward the context. For example: "Hello?", "How are you?". Metalingual function is using utterance to analyze language on the code. For example: "Tit for tat bro". And poetic function is a set toward message as such focus on the message for its own sake (Jakobson, 1987). For example : "Smurf"

The researcher chooses the theory of R. Jakobson for her research, because this theory is very suitable for literary word. By using this theory, the researcher hopes that the students or readers will be easier to understand a meaning of the utterance in learning languge functions.
In this research, this movie contain with spy-thriller genre. According to Jamie (2014), spy-thriller genre is the types of sub-genre focuses on the travels and adventure of agents in the office. In spythriller genre, the main character often fails, it means that there is almost always a chance evil take over or a war accross the word will take place.

\section{METHOD}

This study was designed as mixed method research. This research focus on identifying the six kinds of language function based on R. Jakobson theory in the whole of Now You See Me 2 Movie. Creswell (2008), mixed method research is a procedure for collecting, analyzing and mixing qualitative and quantitative data at the same stage of the research within a singel study in order to understand a research problem more completely. In this method, the researcher will used movie script as the data to be analyzed.

The subject of this research is all the dialogues of the main characters in "Now You See Me 2 Movie". It has 26 scenes that contained the conversation with main characters. The main characters are Dyland Rhodes, Daniel Atlas, Merritt McKnney, Jack Wilder, and Lula. Based on a survey in Bengkulu, this movie released on 10 June 2016 at 21 Cinema Mega Mall and got many viewer, especially English Students of Universitas Bengkulu.

Theinstrument of this research is a table checklist. It is used to categorize data into several groups. In this term, the data are the conversations contain main characters in "Now You See Me 2" Movie. The table consists of 6 rows with different labels. Thye are types of language function, example, code, description, keyword and frequency. The way to set the data are identifying six kinds of language function based on R. Jakobson's theory by looking the keyword (intonation, faced, body language, gestures and body 
movement) aftaer that coding the utterance such as : RF for referential, E for emotive, $\mathrm{C}$ for conative, $\mathrm{PH}$ for phatic, $\mathrm{M}$ for metalingual and $\mathrm{P}$ for poetic. Then count the frequency of each language functions. Finally, researcher will display the data into table of data analysis.

There are several steps to collect the data: (1) Watching Now You See Me 2 movie, (2) Copying the movie script of Now You See Me 2 on www.springfieldspingfield.co.uk,

Looking at and comparing the dialogue in the movie to the movie script to find out whether or not dialogue and script are the same, (4) Identifying the six kinds of R.Jakobson theory in the whole of movie's dialogue that consist of Referential, emotive, phatic, conative, poetic, and metalingual functions by looking at the keyword (intonation, body language, gesture, faced, body movement), (5) Coding and underline the utterance based on R. Jakobson theory ( RF for referential, $\mathrm{E}$ for emotive, $\mathrm{C}$ for conative, $\mathrm{PH}$ for phatic, $\mathrm{M}$ for metalingual and $\mathrm{P}$ for poetic), (6) Count the frequency of the use of each language functions and compare with co-researcher, (7) Display the data into table.

This part of the research will explain about how the way data can get the trustworthiness. The researcher will use triangulation to check the trustworthiness of the data. In analyzing the data, the researcher will be helped by co-researcher, a student of English Education Study Program at Universitas Bengkulu in semester 7 who had learned about language function and he acquired high score in this study. In this research, the

As can bee seen in table 1 , there is little differences on data between the researcher and co-researcher. The coresearcher found that referential function is 255 utterances and the researcher found 258 utterances in the movie. For the phatic function, the co-researcher found 188 researcher and co-researcher will analyze the movie script based on steps and the keyword in research instrument. After that, they will give the utterance 'code' based on six kinds of language function. The data from the researcher and co researcher would be combined and analyzed to find out whether or not there isdifferent finding between the result from data 1 (researcher) and data 2 (co researcher) to get the answer number two.

\section{RESULT AND DISSCUSSION}

\section{A. Kinds of Language Function}

The result of this study showed that from six language function only five language function found by the researcher and coresearcher. The co-researcher analyzed whole of scenes Now You See Me 2 Movie. The result of finding between researcher and co-researcher:

Table 1. The Frequency of Language Function Found by Researcher and CoResearcher

\begin{tabular}{|c|l|c|c|}
\hline $\begin{array}{l}\text { No } \\
1\end{array}$ & $\begin{array}{c}\text { Kinds of } \\
\text { Language } \\
\text { Function }\end{array}$ & $\begin{array}{l}\text { Researcher } \\
\begin{array}{l}\text { Referential } \\
\text { Function }\end{array}\end{array}$ & $\begin{array}{c}\text { Co- } \\
\text { Researc } \\
\text { her }\end{array}$ \\
\hline 2. & $\begin{array}{l}\text { Phatic } \\
\text { Function }\end{array}$ & 187 & 255 \\
\hline 3. & $\begin{array}{l}\text { Emotive } \\
\text { Function }\end{array}$ & 154 & 154 \\
\hline 4. & $\begin{array}{l}\text { Conative } \\
\text { Function }\end{array}$ & 115 & 115 \\
\hline 5. & $\begin{array}{l}\text { Metalingul } \\
\text { Function }\end{array}$ & 18 & 18 \\
\hline
\end{tabular}

utterances and the researcher is 187 utterances. Then, the language function as emotive, conative and metalingual function have the same data between coresearcher and researcher, that is 154 utterances as emotive function, 115 utterances as conative function and 18 utterances as metalingual function. So, it 
means that the analysis from the researcher and co-researcher are similar.

\section{B. What is The Distribution of Language Function Frequency Found in Now You See Me 2 Movie}

\section{The Distribution of Frequency of Language Function}

This movie has 26 scenes. But, not all the functions were appeared in all scene. Here is the table of distribution of frequency of language function :

\section{Table 2. The Distribution of Frequency} of Language Function

\begin{tabular}{|c|c|c|c|c|}
\hline No & $\begin{array}{l}\text { Kinds of } \\
\text { Language } \\
\text { Function }\end{array}$ & $\begin{array}{c}\text { The Total } \\
\text { Number } \\
\text { of Scene } \\
\text { Where } \\
\text { The Items } \\
\text { Were } \\
\text { Found }\end{array}$ & $\begin{array}{c}\text { Frequen } \\
\text { cy of } \\
\text { Languag } \\
\text { e } \\
\text { Functio } \\
\text { n }\end{array}$ & $\%$ \\
\hline 1. & $\begin{array}{l}\text { Referential } \\
\text { Function }\end{array}$ & Out of 24 & 258 & 35.2 \\
\hline 2. & $\begin{array}{l}\text { Phatic } \\
\text { Function }\end{array}$ & Out of 23 & 187 & 25.5 \\
\hline 3. & $\begin{array}{l}\text { Emotive } \\
\text { Function }\end{array}$ & Out of 22 & 154 & 21.0 \\
\hline 4. & $\begin{array}{l}\text { Conative } \\
\text { Function }\end{array}$ & Out of 21 & 115 & 15.8 \\
\hline 5. & $\begin{array}{l}\text { Metalingual } \\
\text { Function }\end{array}$ & Out of 10 & 18 & 2.5 \\
\hline \multicolumn{3}{|c|}{ Total } & 732 & 100 \\
\hline
\end{tabular}

Based on table of distribution of language function, there were 26 scenes that contained conversation of the main characters. From 26 scenes, referential function appeared in 24 scenes with 258 utterances (32.5\%), phatic function appeared in 23 scenes with 187 utterances (25.5\%),emotive function appeared in 22 scenes with 154 utterances (21.0\%), conative function appeared in 21 sceneswith 115 utterances (15.8\%), and metalingual function appeared in 10 sceneswith 18 utterances $(2.5 \%)$. The referential function exists in24 scene because this movie is a sequel of Now You See Me 2013. It means that the information was true or based on the fact, and it can be proved. The distribution of language functions in a movie depends on the situation of the movie itself. Due to the genre of the movie which is spy-triller and contains many conversations, referential function mostly appears than others functions. Phatic, emotive, conative, and metalingual function do not always appear in every scene because this movie only describes or explains small talk or greetings, showed emotion, giving command, and code in certain situation.

\section{The Occurance of Dominant Language Functions}

As finding of the research, it was found that there were three kinds of language function that were dominantly used in Now You See Me 2 movie. Here is the table of the occurance of three dominant language function used :

Table 3. The Occurance of Dominant Language Functions

\begin{tabular}{|c|c|c|c|}
\hline No. & $\begin{array}{l}\text { Kinds of } \\
\text { language } \\
\text { function }\end{array}$ & Frequency & $\%$ \\
\hline 1. & $\begin{array}{l}\text { Referential } \\
\text { Function }\end{array}$ & 258 & 43.07 \\
\hline 2. & $\begin{array}{l}\text { Phatic } \\
\text { Function }\end{array}$ & 187 & 31.22 \\
\hline 3. & $\begin{array}{l}\text { Emotive } \\
\text { Function }\end{array}$ & 154 & 25.71 \\
\hline \multicolumn{2}{|r|}{ Total } & 599 & 100 \\
\hline
\end{tabular}

As can be seen in table 3 , the most dominant language function is referential function. It was found there were 258 utterances that contained referential function. This function appears when the main characters give the right information about something. The second dominant language function is phatic function. It was found that there were 187 utterances that contained phatic function. This function was mostly used when the main characters tried to open the communication or making a small talk. Emotive function is the third dominant language function used which 
was found in 154 utterances in Now You See Me 2 movie. This function was mostly used in scene 29. In this scene, Lula used emotive function to expresess her feeling. The horsemen were caught by Walter's goons and were taken to his plane. As they take off, Chase suggests that they throw them all of the plane which makes Lula as a single ladies in The Horsemen affraid and worried. Thus, she uses many utterances that contain emotive function in the movie.

\section{The Absence of Poetic Function in} The Movie

In this research, it was found that poetic function was not used in Now You See Me 2 movie. Poetic function is the expressing interest, feeling, attitudes and many other in the form of poetry (Arum, 2014). In the movie, the main characters used to the point utterances for all the conversation. The researcher did not find any beautiful language in the movie. The main characters sometimes used slang language in the conversation.

\section{Discussion}

As presented in the finding section, it was found that there were five out of six language functions used by the main characters in "Now You See Me 2" movie. They are referential function, emotive function, conative function, phatic function, and metalingual function. It means that the main characters in "Now You See Me 2" movie used language functions based on the situations and topics of converstion. The occurance of these language functions also depends on the genre of the movie. The genre of this movie is spy thriller which contains elements of war, travel, action and adventure. Due to the genre of the movie which is spy-thriller, poetic function was not found because this function was only found in a romantic genre, musical/dance film genre, novel, song and animation genre. Thus, the researcher only found five language functions fom six language function. According to Jakobson (1987), poetic function is the utterances where the dominant in literary texts and the language tends to be more "opaque" than conventional prose.

It can be seen from the result, the distribution of the frequency of language function was referential function $(35.2 \%)$, it was the dominant probably because this movie is a sequel of Now You See Me 2013. In several part or scenes, the main characters give the information about something happened in the past and it still happen now. This function also appears based on the situation and topic of the conversation. If the information was right and it can be proved that was a referential function.

Phatic function $(25.5 \%)$, it was appeared when the main characters tried to opened the communication, making small talk and keeping talking to someone else. This function usually used in the beggining of the conversation or meeting a new people like greetings "Hello. How are you?", mentioning names, title "Atlas!", Mr. Potter!", commenting on something obvious "Hi. You are busy!" and interrupting "Excusme. Can I borrow your time for a minute?". So, this movie used all of it. Like in scene 12, the horsemen go to magic shop in Macau. They meet Lee, and tried to make the conversation by using greetings.

Then, the distribution of emotive function $(21.0 \%)$, it was appeared when the main characters express their emotion due to dangerous or exciting moment. In several scenes, the main characters were in danger situation like Dyland drop into the river, and when the horsemen thrown of the plane by Walters' bodyguards.

Conative function $(15.8 \%)$, it was appeared when someone give the command to others. In this movie, the most dominant used this function was Dyland Rhodes because he is the leader of the horsemen. He gave a command to the 
horsemen when they wanted to performance on the stages, or they have a great job.

Metalingual function (2.5\%), it appeared when the main characters used some code or implicit meaning to others. This function mostly used by Merritt McKnney because he liked to joking others people.

Poetic function $(0 \%)$, it was not found because the situation and the genre of the movie was not suitable for the use of this language function. According to Arum (2015), phoetic function is mostly found in novels, romantic movies and songs. On the other hand, the genre of Now You See Me 2 Movie is spy-thriller, where the use of language tends to be imperative, to the point and straightforward. So, that why poetic function did not appear in the movie.

Based on the explanation of the distribution of each language function, it found that there were three most dominant language functions in "Now You See Me 2" movie which were referential function, phatic function and emotive function. Referential function appears when the main characters try to says the right information about something. According to Arista (2014), referential function is an information carrier.It could be described a situation, object or mental state such as "The eart is round" and "The party is crowded". Due to this movie is a sequel of Now You See Me (2013), in some situations the main characters used referential function to recalls the memories in the past or in previous movie. This functions also appears when the main characters saidsomething had happened, their activity and it can be proved it. Such as in scene 5, Daniel Atlas gives the information to Jack and Merritt about someone who broke into his apartment and Lula knows everything about him, the horsemen and Henley's leaving. This utterance is found to be true in scene 4, because Lula comes to Daniel apartment and she says everything about the horsemen and something happend in the past.

According to Cook (1989), phatic function is the opening the channel or checking that it is working ("Hello," "lovely weather", "Do you come here often?" or for pratical ones ("Can you hear me?"). In this research, phatic function appears in several scene of the movie and this function used to open the communication. In this movie, the genre is spy-thriller genre. Spy thriller genre is a sub-genre of thriller. It focuses on the travels and adventure of agents in the office or on the field. This movie took place in several places such as Macau, NewYork and London. They meet many new people and have some gripping situation. To open the communication such as greeting, asking, changing topic and making a small talk, the main characters always used phatic function. So, that is way phatic function appear in this movie.

Jakobson (1987), states that emotive function is expressive function,focus on the aims a direct expression of the speaker. This function appears when the main characters show their expression, feeling, and interesting. This function gives the information about someone's situation or feeling to the others. It can be seen by observing someone face (face expression) or when someone is going to speak (intonation). This function appears in the movie when the main characters are in bad or creepy situation like scene 29. Creepy situation is when the horsemen was about to be thrown out of the plane.

From the explanation above, the researcher found several differences between the previous study and this research. The first previous study was from Arum (2015) with title "An Analysis of Language Function Found in Enchanted Movie Script" from English Education Department Faculty of Tarbiyah and Teacher Training State Islamic Institute 
(IAIN) of Tulungagung. The results of the research showed that some language functions found in "Enchanted" movie script were emotive function, directive function, phatic function, poetic function, referential function, metalinguistic function and contextual function and the researcher found some messages and communicating forms of the message in the movie script. The language functionwhich mostly appears in sentences of "Enchanted" movie script isdirective function. In this research, the researcher found that referential function was the most dominant used of language function, because in this movie, the main characters often shows the fact, and giving the right information.

Another study was from Arista (2014) with title Language Functions Used By The Main Character In Sherlock

\section{CONCLUSION}

After analysing the usage of language function by the main characters of Now You See Me 2 movie the conclusion can be explained as follow: (1)Out of possible language function only five language function found in "Now You See Me 2 movie". They were referential function, emotive function, conative function, phatic function and metalingual function. (2)The distribution of language functions in this research showed that there were 26 scenes that contained conversation of the main characters. From 26 scenes, referential function appeared in almost of the scenes with 258 utterances (35.2\%) out of 24 scenes, phatic function was 187 utterances (25.5\%) out of 23 scenes, emotive function was 154 utterances $(21.0 \%)$ out of 21 scenes, conative function was 155 utterances $(15.8 \%)$ out of 21 scenes, metalingual function 18 utterances $(2.5 \%)$ out of 10 scenes and poetic function was 0 utterance $(0 \%)$. (3)Among the five language functions, the researcher found that there were three kinds of language function that were mostly used in the
Holmes II : A Game Of Shadows Movie. The result of this research was there were 6 language functions found in the movie based on Cook's theory. They were expessive function, directive function, referential function, metalinguistic function, phatic function and poetic function. Another result showed that the dominant types of language function was metalinguistic function. Meanwhile, in this research, the researcher found that the dominant types of language function Used in Now You See Me 2 movie was Referential function. It happen because the movie was a sequel of the previous movie and the main characters was a group of magician (the horsemen). So, they give right information each other. Sometime, they talked about what happen to them, the fact and it can be prove it.

movie. They were referential function, phatic function and emotive function. (4) Poetic function was not found because the situation and the genre of the movie was not suitable for the use of this language function. The main characters did not use a beautiful language in the scene. This movie was spy-thriller genre which means that the conversation used straight to the point language. Sometimes they use impolite and slang words in the conversation.

Based on the explanation above, it can be concluded that the conversation of this movie is very clear and to the point. The researcher did not found poetic function because the genre of this movie is spythriller. This genre contains the combination of action, adventure, travel and politic. So, the main characters do not use a beautiful language.

In this section, the researcher would like to give some suggestions as follow: (1) For the readers and students, this research will be reference and give them the more information about learning language function especially in learning 
discourse analysis and functional grammar. Because those of study related to languge function. (2) This study can be reference for teachers in teaching and learning linguistics especially in functional grammar or discourse analysis. The teachers can use a movie as a media to give background knowledge about language functions to the students. (3) For the future researcher, this research can be used as reference for another study about language function because this study have many theorist, so you can choose it. Moreover, the researcher suggests the future researcher to analyze language function in speech, advertisement, novel and social media (facebook, instagram or twitter).

\section{REFERENCES}

Arista, Sri DeviandMurni, Sri Minda (2014) :'Language Functions Used By The Main Character In Sherlock Holmes Ii: A Game Of Shadows Movie'. UniversitasNegeri Medan.

Arum, Nova Puspita. 2015. An Analysis of Language Function Found in Enchanted Movie Script. IAIN Tulungagung

Arwood, Ellyn L. 2011. Language Function : An Introduction to

Jakobson, Roman. 1987. Language in literature. London, England:
Pragmatic Assessment and Intervention fo Higher Order Thinking and Better Literancy. London N1 9JB, UK.

Barsam, Richard and Dave Mohanan.Looking at movies: An Introduction to Film. New York.

Bordwell, D., and K. Thompson.2008. Film Art: An Intoduction. New York: Me Graw-Hill.

Beatty, Jamie. 2014. Genre Research.

Retrivred on November $5^{\text {th }} 2014$

from.https://www.slideshare.net/jamiethomas

beatty/spy-thriller-genre-research-41148678

Cook.G .1989.Discourse.Oxford University Press.

Creswell, J.W. 2008. Educational Research :planning conducting and evaluating quantitativeand qualitative approaches to research (3rd.ed). Upper Saddle River,New Jersey: Merrill/Pearson Education.

Hasist, Muhammad (2007). An analysis of language function used by Marcus Burnet in Bad Boys II film. Jakarta : Universitas Syarif Hidayahtull.

Harvard University Press. Cambridge, Massachusetts. 